\title{
Protein-Polymer Conjugates Synthesized Using Water-Soluble Azlactone-Functionalized Polymers Enable Receptor-Specific Cellular Uptake toward Targeted Drug Delivery
}

\author{
Julia S. Kim ${ }^{\dagger, \#}$, Allison R. Sirois ${ }^{\ddagger, \S, \#, ~ A n a l i a ~ J . ~ V a z q u e z ~ C e g l a ~}{ }^{\ddagger, \#}$, Eugenie Jumai'an ${ }^{\ddagger}$, Naomi \\ Murata $^{\perp}$, Maren E. Buck ${ }^{*}, \|$, and Sarah J. Moore ${ }^{*}, \neq, \nabla$ \\ †Biochemistry Program, Smith College, Northampton, Massachusetts 01063, United States \\ ‡Picker Engineering Program, Smith College, Northampton, Massachusetts 01063, United States \\ ${ }^{\perp}$ Neuroscience Program, Smith College, Northampton, Massachusetts 01063, United States \\ "Department of Chemistry, Smith College, Northampton, Massachusetts 01063, United States \\ ${ }^{\nabla}$ Department of Biological Sciences, Smith College, Northampton, Massachusetts 01063, United \\ States
}

$\S$ Molecular and Cellular Biology Program, University of Massachusetts Amherst, Amherst, Massachusetts 01003, United States

\section{Abstract}

Conjugation of proteins to drug-loaded polymeric structures is an attractive strategy for facilitating target-specific drug delivery for a variety of clinical needs. Polymers currently available for conjugation to proteins generally have limited chemical versatility for subsequent drug loading. Many polymers that do have chemical functionality useful for drug loading are often insoluble in water, making it difficult to synthesize functional protein-polymer conjugates for targeted drug delivery. In this work, we demonstrate that reactive, azlactone-functionalized polymers can be grafted to proteins, conjugated to a small-molecule fluorophore, and subsequently internalized into cells in a receptor-specific manner. Poly(2-vinyl-4,4-dimethylazlactone), synthesized using reversible addition-fragmentation chain transfer polymerization, was modified post-

polymerization with substoichiometric equivalents of triethylene glycol monomethyl ether to yield reactive water-soluble, azlactone-functionalized copolymers. These reactive polymers were then conjugated to proteins holo-transferrin and ovotransferrin. Protein gel analysis verified successful conjugation of proteins to polymer, and protein-polymer conjugates were subsequently purified from unreacted proteins and polymers using size exclusion chromatography. Internalization experiments using a breast cancer cell line that overexpresses the transferrin receptor on its surface showed that the holo-transferrin-polymer conjugate was successfully internalized by cells in a

\footnotetext{
*Corresponding Authors: mbuck@smith.edu. sjmoore@smith.edu.

\#J.S.K., A.R.S., and A.J.V.C. contributed equally to this work.

The authors declare no competing financial interest.

ASSOCIATED CONTENT

Supporting Information

The Supporting Information is available free of charge on the ACS Publications website at DOI: 10.1021/acs.bioconjchem.

9b0015510.1021/acs.bioconjchem.9b00155.
} 
mechanism consistent with receptor-mediated endocytosis. Internalization of protein-polymer conjugate demonstrated that the protein ligand maintained its overall structure and function following conjugation to polymer. Our approach to protein-polymer conjugate synthesis offers a simple, tailorable strategy for preparing bioconjugates of interest for a broad range of biomedical applications.

\section{Graphical Abstract}

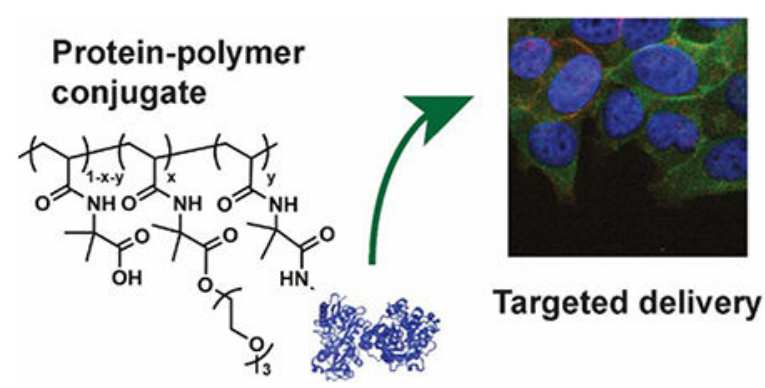

\section{INTRODUCTION}

Treatment of numerous diseases could benefit from improved options for targeted delivery of drugs to disease-specific locations. Two important challenges in medicine for which targeted delivery could significantly improve patient outcomes are delivery of therapeutics to the central nervous system and delivery of chemotherapeutics selectively to tumor cells. The blood-brain barrier (BBB) frequently prevents therapeutics from sufficiently accessing brain tissue, creating a major bottleneck for developing treatments for diseases like Alzheimer's disease and brain tumors. ${ }^{1,2}$ Often, drug development efforts for neurological diseases must focus on small-molecule candidates constrained by a set of physicochemical properties that can facilitate their passage across the BBB. ${ }^{3}$ Receptor-mediated transcytosis (RMT) is a promising approach being developed to use native transport pathways to shuttle larger therapeutic complexes across the BBB. ${ }^{4,5}$ Initial reports of the ongoing clinical trials for the first RMT-based therapeutic to be used in humans have been positive, ${ }^{6}$ encouraging continued development of therapeutics using RMT pathways for drug delivery.

Specific targeting of chemotherapeutic agents to tumor cells could significantly reduce toxic side effects that are currently caused by the systemic distribution of administered cytotoxic drugs in the body. ${ }^{7}$ In recent years, substantial progress has been made toward the general goal of targeted therapy using both passive and active targeting approaches. ${ }^{7}$ For example, antibody-drug conjugates have been developed that rely on the specific targeting of tumor biomarkers using antibodies to deliver a toxic payload to tumor cells. ${ }^{8-10}$ There are, however, challenges with finding appropriate chemistries for conjugating the drug to the antibody, with continued need for improved linkers between antibodies and their drug payload that do not inhibit antibody targeting and that can release drug when the conjugate has reached the desired location. ${ }^{8}$ Inorganic and polymeric nanocarriers have also been explored for both passive and active targeting. ${ }^{11,12}$ Although several nanocarriers that passively target tumor cells have been approved for clinical use, no actively targeted 
nanocarriers have advanced past clinical trials to date. ${ }^{12}$ There remains a need for better drug carriers that actively target pathological cells.

Active targeting of drug carriers to particular cell types is generally achieved by conjugating a drug carrier to a ligand that binds specific cell-surface receptors. Drug carriers include polymers and nanoparticles, and ligands can be proteins, peptides, or certain small molecules. ${ }^{7,11,12}$ Proteins are particularly useful as targeting ligands because they exhibit precise binding interactions with molecular partners. Protein engineering permits the manipulation of these binding interactions such that a given targeting protein can be engineered to meet identified design parameters, such as a desired affinity or binding epitope on the receptor. ${ }^{13,14}$ Consequently, proteins, including antibodies and other protein classes, have found wide success on their own as therapeutics for a variety of diseases. ${ }^{15,16}$ To be useful as a targeting ligand for drug delivery applications, proteins that interact with a chosen disease marker need to be chemically coupled to the drug to be delivered. Versatile and straightforward chemistries to conjugate drugs to proteins are still needed. ${ }^{8}$ Polymers that link targeting proteins to drug molecules are a promising avenue for developing a modular strategy for synthesizing targeted drug delivery molecules, where any targeting protein of interest could be readily coupled to a drug molecule linked by a polymer that couples to protein and to drug. Here, we report the development of protein-polymer conjugates for targeted drug delivery applications.

Protein-polymer conjugates are being used in a variety of applications in medicine and industry. ${ }^{17-19}$ The first generation of protein-polymer conjugates were comprised of polyethylene glycol (PEG) attached to therapeutic proteins to extend the circulation time and reduce the immunogenicity of the therapeutics. Over the past several decades, more than a dozen PEGylated molecules have been approved for use in humans. ${ }^{20-22}$ While PEG continues to be the leading polymer for preparing clinically relevant protein-polymer conjugates, PEG does have limitations, such as non-degradability and potential immunogenicity, ${ }^{23}$ that necessitate the development of protein-polymer conjugates with an expanded selection of finely tuned functionalities.

Numerous advances in the development of protein-polymer conjugates with expanded chemistries useful for biomedical applications have been reported in recent years. ${ }^{17-19,24,25}$ Strategies for controlled polymerization ${ }^{19,24-26}$ and site-specific conjugation ${ }^{24,25,27-34}$ of polymers to proteins have facilitated the synthesis of more well-defined protein-polymer conjugates. Site-specificity and control of polymer synthesis are jointly achieved with approaches that grow polymers from proteins functionalized with an initiator at a unique location in the protein sequence. ${ }^{24,31,33}$ While growing polymers from appropriately functionalized proteins, termed "grafting-from", affords more easily purified conjugates, 19,25,26 the grafting-from approach does limit to some extent the chemistries that can be incorporated into the polymer structure. In addition, grafting-from requires a new polymer to be synthesized each time the bioconjugate is prepared, which may lead to small variations in the polymer structure, even when controlled methods are used. In a "grafting-to" approach, preformed polymers bearing end-group or side-chain reactive functionality are conjugated to proteins. ${ }^{25,35,36}$ A number of different chemistries have been used to facilitate grafting of polymers to proteins, including polymers bearing amine-reactive functionality such as 
NHSesters or anhydrides, ${ }^{25,36,37}$ maleimide or dibromomaleimide functionality for reaction with cysteine residues, ${ }^{25,36,38-40}$ and bioorthogonal "click" reactions. ${ }^{25,34,36,41}$ Grafting-to permits incorporation of both water-soluble and water-insoluble functionalities into the polymer structure. For example, hydrophobic drugs are an important class of water-insoluble molecules that can be incorporated into polymer structures when using the grafting-to approach. Grafting-to also allows conjugation of a defined polymer structure to a variety of different proteins.

In the work reported here, we explored the use of side-chain reactive polymers for the preparation of protein-polymer conjugates via a grafting-to approach. Side-chain reactive polymers and their subsequent post-polymerization modification ${ }^{42-45}$ offer opportunities for combinatorial synthesis of a broad range of polymer structures such that the influence of polymer structure on bioconjugate properties can be easily explored. ${ }^{46}$ Furthermore, these reactive groups could be used to tether drug molecules to the scaffold before protein conjugation. In particular, hydrophobic drugs can be more readily coupled to a polymer in organic solvent compared to directly coupling a hydrophobic drug to a protein in aqueous solution. From a drug delivery perspective, a polymer with a tunable number of sites for drug attachment is desirable because it permits intentional selection of the number of drug molecules per protein-polymer conjugate. Such flexibility in drug loading enables targeting an appropriate concentration in the body within a particular drug's therapeutic window. It is then possible to achieve a sufficiently high concentration of the drug at the disease site to have a desired therapeutic effect while remaining below concentrations in the body that cause unacceptable toxicities. The ability to conjugate a variety of active drug molecules directly to protein residues is more limited compared to approaches that use a delivery scaffold.

We used the reactive polymer poly(2-vinyl-4,4-dimethylazlactone) (PVDMA, Figure 1) to prepare a series of protein-polymer conjugates. PVDMA is attractive for the preparation of bioconjugates for several reasons. It can be synthesized from the vinyl monomer using a variety of polymerization methods. ${ }^{43,45,47}$ In this current work, we synthesized PVDMA using reversible addition-fragmentation chain transfer (RAFT) polymerization, which has been demonstrated previously to yield well-defined azlactone-functionalized polymers (Figure 1A). ${ }^{47-50}$ Importantly for this work, the five-membered lactone of PVDMA rapidly undergoes ringopening reactions with nucleophiles, such as amines and alcohols, including those found in native proteins. ${ }^{45,51}$ Thus, a broad range of polymeric structures and bioconjugates can be readily synthesized starting from the same template polymer. While azlactone-functionalized polymers have been used to immobilize proteins on a variety of solid supports or thin films, ${ }^{45,51}$ only a few examples of soluble protein-polymer conjugates have been reported. ${ }^{48,52,53}$ For example, Fontaine and co-workers demonstrated the feasibility of using the azlactone functional group for conjugation of polymers to lysozyme ${ }^{48,52}$ while Weeks et al. reported the conjugation of recombinant elastin-like polypeptides to PVDMA. ${ }^{53}$ However, because PVDMA is not inherently water-soluble, these previous reports used organic solvents to conjugate the protein to the polymer. ${ }^{48,52,53}$

In this work, we demonstrate the feasibility of synthesizing water-soluble, azlactonefunctionalized polymers and conjugating these reactive polymers to disease-relevant 
proteins. Stover and co-workers reported the synthesis of water-soluble azlactonefunctionalized polymers through copolymerization of the azlactone monomer VDMA with a series of water-soluble comonomers. ${ }^{54}$ Others have demonstrated that PVDMA can be rendered water soluble by exhaustive functionalization with appropriate side chain functionality. ${ }^{55}$ In the work described in this report, we functionalized PVDMA with substoichiometric amounts of triethylene glycol monomethyl ether (abbreviated mTEG) to prepare reactive, water-soluble polymers (PVDMA-mTEG, Figure 1A). This polymer readily conjugates to the proteins holo-transferrin (hTF) and ovotransferrin (OTF) in aqueous solution (Figure 1B). hTF represents a useful model protein for the development of targeted drug delivery scaffolds because the protein binds to and is internalized by cellsurface transferrin receptors (TFR) present on endothelial cells that comprise the blood-brain barrier and expressed at high levels on many tumor cells. ${ }^{56} \mathrm{hTF}$ has also been used recently in the synthesis of protein-polymer conjugates and shown to facilitate receptorspecific targeting of conjugates to cells expressing the transferrin receptor. ${ }^{57}$ Using confocal microscopy assays, we observed that hTF-PVDMA-mTEG conjugates were internalized specifically into a tumor cell line that expresses TFR. This work exemplifies a modular approach for synthesizing protein-polymer conjugates and offers a new system that can be easily tailored for targeted drug delivery to a variety of diseasespecific cell types.

\section{RESULTS AND DISCUSSION}

\section{Synthesis and Characterization of mTEG-Functionalized PVDMA}

PVDMA was synthesized using RAFT polymerization ${ }^{58}$ (Figure 1A, step 1) to yield a welldefined homopolymer with $M_{\mathrm{n}}=13.1 \mathrm{~kg} / \mathrm{mol}$ (Table 1). Water-soluble azlactonefunctionalized polymers for protein conjugation were synthesized by treating the homopolymer with 0.3 equiv of mTEG relative to the azlactone repeat unit (Figure 1A, step 2). DBU was used as a base catalyst and all reactions were stirred at $40{ }^{\circ} \mathrm{C}$ overnight. Figure 2A shows FT-IR spectra of PVDMA homopolymer and PVDMA treated with mTEG. The IR spectrum of PVDMA prior to functionalization (Figure 2A, black dashed curve) revealed peaks characteristic of the carbonyl $\left(1820 \mathrm{~cm}^{-1}\right)$ and imine $\left(1670 \mathrm{~cm}^{-1}\right)$ bonds of the azlactone ring. Treatment of PVDMA with 0.3 equiv of mTEG (red curve) led to a decrease in the carbonyl and imine peaks and the appearance of peaks at $1735 \mathrm{~cm}^{-1}$ (ester), $1650 \mathrm{~cm}$ ${ }^{-1}$ (amide I), and $1540 \mathrm{~cm}^{-1}$ (amide II) that result from ring-opening of the lactone with an alcohol nucleophile. Quantitative analysis of mTEG functionalization using ${ }^{1} \mathrm{H}$ NMR spectroscopy revealed that mTEG was incorporated into the polymer in nearly quantitative yield (Table 1). Gel-permeation chromatography (GPC) analysis of PVDMA functionalized with mTEG revealed an increase in molecular weight consistent with functionalization of the polymer (Table 1). GPC analysis also confirmed that no polymer cross-linking occurred during treatment with mTEG, based on observing no increase in dispersity comparing polymer before and after mTEG functionalization. The absence of cross-linking is expected since mTEG only has one nucleophile that is reactive with the azlactone group. Finally, while PVDMA can be functionalized with larger amounts of mTEG, polymers modified with 0.3 equiv proved to be soluble in water and in phosphate buffered saline (PBS). Thus, this polymer, referred to hereafter simply as PVDMA-mTEG, was used for all experiments 
described here to provide the greatest number of remaining reactive groups in the polymer for additional modifications and protein conjugation.

One potential challenge associated with using the azlactone moiety for protein conjugation in aqueous solution is that these groups are susceptible to hydrolysis. However, hydrolysis reactions are typically slower than reactions of azlactones with amines. Furthermore, azlactone groups have been shown to persist for several hours in water when copolymerized with certain water-soluble monomers. ${ }^{54}$ To qualitatively characterize the rate of hydrolysis of PVDMA-mTEG, we acquired IR spectra of a polymer dissolved in water (Figure 2B) over time. The series of spectra shown in Figure 2B revealed that the lactone carbonyl peak (1820 $\mathrm{cm}^{-1}$ ) decreased but remained present over a period of at least $12 \mathrm{~h}$ in water, suggesting some, but not complete, hydrolysis of azlactone functionality. The polymer fully hydrolyzed in $24 \mathrm{~h}$ as evidenced by the complete disappearance of the lactone carbonyl peak at $1820 \mathrm{~cm}$ ${ }^{-1}$ (Figure 2B). Based on these data, we hypothesized that, following functionalization with mTEG, sufficient azlactones would remain on the polymer to permit reaction with amines on a protein (i.e., the $\mathrm{N}$-terminus or lysine residues), but that all residual azlactone groups would fully hydrolyze during or after protein conjugation. This latter hydrolysis reaction is desirable in order to avoid unwanted reactions of the polymer with proteins on cells in subsequent cell internalization experiments.

\section{Protein Holo-transferrin Conjugates to PVDMA-mTEG}

For our initial experiments, holo-transferrin (hTF) was selected to determine the feasibility of conjugating proteins to PVDMA-mTEG. hTF is an $80 \mathrm{kDa}$ glycoprotein containing 58 lysine residues (UniProt P02787) and is the native protein ligand for the transferrin receptor (TFR). ${ }^{56}$ Upon binding its receptor, hTF gets internalized into cells through receptormediated endocytosis. The hTF-TFR interaction is of interest for a variety of clinical applications. ${ }^{56}$ For example, receptor-mediated transcytosis facilitated by TFR has been studied for drug delivery across the blood-brain barrier to the central nervous system. ${ }^{59} \mathrm{TFR}$ is also overexpressed in many cancers, which makes it an interesting receptor system to be used as a model for targeted drug delivery to tumor cells. ${ }^{60}$ Because PVDMA reacts readily with the primary amines in the N-termini and lysine residues in proteins,${ }^{45,51} \mathrm{hTF}$ provides ample reactive sites for conjugation.

Conjugates were prepared by incubating PVDMA-mTEG with hTF in PBS containing 15\% $\mathrm{v} / \mathrm{v}$ DMSO at $4{ }^{\circ} \mathrm{C}$. Low concentrations of DMSO are commonly used to facilitate conjugation of reactive small molecules and polymers to proteins. ${ }^{37,61}$ We examined a range of molar ratios of polymer:protein for hTF conjugation reactions. Successful conjugation of polymer to protein was assessed using SDS-PAGE (Figure 3). Lane 1 contained pure hTF protein with no polymer. Lane 2 contained PVDMA-mTEG polymer with no protein, which was not detected by the protein gel stain. Lanes 3 through 6 included conjugation reactions in which the amount of protein was kept constant while the amount of PVDMA-mTEG was increased. Lane 3 revealed the presence of a faint band at higher molecular weight than the hTF protein band. The apparent molecular weight of this band was consistent with the molecular weight of one protein and one polymer molecule, suggesting the formation of conjugates at a 1:1 molar ratio of protein:polymer. With greater amounts of polymer in the 
conjugation reaction (Figure 3, lanes 4-6), we observed a band at a molecular weight consistent with a protein:polymer molar ratio of 1:2. Increasing the molar amount of polymer relative to protein resulted in a darkening of this higher molecular weight band. We did not observe any protein bands at a molecular weight that suggested two or more proteins in a conjugate molecule with at least one polymer. While all reactions showed residual unreacted protein, as demonstrated by the presence of the original protein band in lanes 3-6, the intensities of these bands were increasingly reduced compared to the intensity of the protein only sample shown in lane 1 . The same amount of total protein was loaded into lanes 1 and 3-6, and, therefore, reduction in the original protein band intensity further suggested successful protein-polymer conjugation. Taken together, these data demonstrated that hTF conjugates to PVDMA-mTEG through reactive, azlactone functionality in aqueous solution.

\section{Protein-Polymer Conjugates Can Be Purified by Size Exclusion Chromatography}

Prior to use in receptor targeting experiments with a human cell line, protein-polymer conjugates were purified from unreacted protein and unreacted polymer. Samples were first concentrated and purified from low molecular weight species by using a centrifugal filtration device with a $10 \mathrm{kDa}$ molecular weight cutoff (MWCO) before being loaded onto a size exclusion chromatography (SEC) column. Samples were analyzed by detecting absorbance at $220 \mathrm{~nm}$. Pure hTF protein exhibited a single narrow peak on SEC (Figure 4A, red solid curve). PVDMA-mTEG exhibited a broad high-molecular-weight peak and a narrow lowmolecular-weight peak (Figure S1A). Unpurified protein-polymer conjugates eluted at shorter retention times (i.e., higher molecular weight) relative to hTF only and included lowmolecular-weight species similar to polymer only samples (Figure 4A, black dashed curve). We were able to collect the high-molecular-weight protein-polymer conjugate peak, which no longer contained unreacted protein when analyzed by SEC (Figure 4A, red dashed curve) and SDS-PAGE (Figure 4B). Because the molecular weight of the polymer is less than the molecular weight of the protein, we anticipated that most or all of the unreacted polymer was removed through SEC purification. However, because polymer alone does not stain on the protein gel, it is possible that some unreacted polymer remained following SEC purification. Yields were routinely on the order of $20 \%$, defined as mol purified proteinpolymer conjugate/mol protein in initial conjugation reaction.

The purified protein-polymer conjugates contained a mixture of conjugates at protein:polymer ratios of 1:1 and 1:2 (Figure 4B). On SEC, we did not observe any products of the conjugation reaction that would suggest more than one protein per conjugate, based on analysis of retention time of the protein-polymer conjugation reactions. However, it is possible that any conjugates with two proteins joined by one or more polymers may have eluted at a longer retention time than would be predicted for a globular protein of the same molecular weight, so it remains possible that some protein-polymer conjugates containing two proteins existed in our reaction mixture. The lack of molecules in the conjugation reaction mixture eluting at less than 20 min retention time conclusively indicated a lack of higher order aggregates. 


\section{Fluorescent Small Molecule Can Be Coupled to PVDMA-mTEG Prior to Polymer Conjugation to Protein}

To permit visualization of protein-polymer conjugates in the presence of cells using fluorescence imaging techniques, we fluorescently labeled PVDMA-mTEG with the aminefunctionalized fluorophore fluorescein cadaverine (FC, labeled polymer denoted as PVDMA $\left.A_{F C}-m T E G\right)$. Coupling a small-molecule fluorophore directly to the polymer models a way in which drugs could be tethered to the polymer for future drug delivery applications. FC was reacted with PVDMA-mTEG in DMSO in a molar ratio of FC to azlactone such that 1-2 molecules of FC were coupled to each polymer chain. Many small-molecule drugs are hydrophobic, and the ability to couple drugs to polymer in organic solvent prior to an aqueous reaction conjugating polymer to protein is an advantage of our approach. We then coupled the fluorescently labeled PVDMA $\mathrm{FC}_{\mathrm{FC}}-\mathrm{mTEG}$ to $\mathrm{hTF}$ and to the protein ovotransferrin (OTF). OTF is the chicken homologue of human transferrin. It has the same overall structure and size as human hTF, but is sufficiently distinct in sequence that it does not bind to human TFR, ${ }^{62}$ making OTF conjugates a suitable negative control for TFR binding and internalization experiments. FC labeled protein-polymer conjugates were purified from unreacted molecules by SEC as described above, yielding a single pure peak when analyzed by SEC (Figure 5A). The peak exhibited absorbance at $220 \mathrm{~nm}$ (Figure 5A, top) and at $494 \mathrm{~nm}$ (Figure 5A, bottom). Absorbance at $494 \mathrm{~nm}$ is characteristic of the fluorophore, and was absent in the sample of pure protein, indicating successful conjugation of $\mathrm{FC}$ to polymer, and subsequent conjugation of $\mathrm{PVMDA}_{\mathrm{FC}}-\mathrm{mTEG}$ to protein. Analysis of the purified FC labeled protein-polymer conjugates using UV-visible spectroscopy resulted in absorbance peaks at 280 and $494 \mathrm{~nm}$ (Figure 5B). In pure hTF protein, there was only an absorbance peak at $280 \mathrm{~nm}$. In PVDMA-mTEG without FC conjugation, we saw no absorbance peaks in the UV-visible range, as expected (Figure S1B). The presence of the $494 \mathrm{~nm}$ absorbance peak in the FC-coupled PVMDA-mTEG and in the purified proteinpolymer conjugates confirmed that FC was successfully conjugated to PVDMA-mTEG and that PVDMA $\mathrm{FC}-\mathrm{mTEG}$ subsequently was able to be conjugated to hTF and OTF.

\section{Internalization of Protein-Polymer Conjugates into Cells Is Receptor-Specific}

We next determined that protein-polymer conjugates were specifically internalized through receptor-mediated endocytosis. MCF-7 breast cancer cells have been shown to overexpress the transferrin receptor on their surface and have been previously used to study internalization of molecules targeted to TFR. ${ }^{63,64}$ Flow cytometry with an antibody that recognizes human TFR confirmed high levels of surface TFR expression on the MCF-7 cell line (Figure S2A). A titration binding assay was performed with fluorescently labeled hTF and MCF-7 cells to determine an appropriate concentration of protein or protein-polymer conjugate for cell internalization experiments. We determined a dissociation constant $\left(K_{\mathrm{D}}\right)$ of $10 \pm 5 \mathrm{nM}$ (Figure S2B), which is consistent with previously reported values. ${ }^{56} \mathrm{~A}$ biological interpretation of the $K_{\mathrm{D}}$ is that half of the receptors are occupied by ligand when the ligand concentration is equal to the $K_{\mathrm{D}}$. In subsequent conjugate internalization experiments, we incubated MCF-7 cells with $10 \mathrm{nM}$ of conjugates to provide ample ligand to visualize receptor-specific internalization, without overwhelming the receptor internalization machinery. 
All internalization experiments were conducted by incubating protein-polymer conjugate samples or control samples with MCF-7 cells for $1 \mathrm{~h}$ at $37^{\circ} \mathrm{C}$ in culture media without serum. These conditions were on the time scale and at the relevant temperature for receptormediated endocytosis to occur in MCF-7 cells. ${ }^{65}$ Prior to imaging, all cells were stained with phalloidin (shown by red fluorescence), which binds to actin filaments and demarcates cell boundaries, and DAPI (shown by blue fluorescence), which stains cell nuclei. All protein, protein-polymer, and polymer samples were fluorescently labeled with either Alexa Fluor 488 (AF488, samples with protein only) or FC (all polymer-containing samples) and are shown as green fluorescence.

Row 1 of Figure 6 shows confocal microscopy images for MCF-7 cells stained with DAPI and phalloidin to identify nuclei and actin filaments, but with no protein, polymer, or conjugates added; these images show the level of background cellular autofluorescence in the channel that was used to visualize targeting molecules. Row 2 of Figure 6 shows confocal microscopy images for MCF-7 cells incubated with $10 \mathrm{nM} \mathrm{hTF-488.} \mathrm{The} \mathrm{green}$ channel and merged images contained punctate regions of green fluorescence distributed throughout the cell body (cell boundaries shown in red channel), indicating internalization of the protein. The presence of punctate structures is consistent with protein localized to endosomes after receptor-mediated endocytosis. When treated with increasing concentrations of hTF-488, MCF-7 cells showed increased levels of internalization and increased signal at the surface of cells (Figure S3), also consistent with receptor-mediated endocytosis as the receptor pathway becomes saturated with ligand. To further demonstrate that ligand-receptor interactions were necessary for internalization, we conducted a competition experiment in which cells were treated with hTF-488 $(10 \mathrm{nM})$ and a 1000-fold excess of unlabeled hTF $(10 \mu \mathrm{M})$ (Figure 6, row 3). As expected, when labeled protein was in competition with an excess of unlabeled protein, green fluorescence signal within the cell body was reduced to the level of background autofluorescence (Figure 6, row 3). The results of these control experiments demonstrated that hTF is internalized into our MCF-7 cells via a mechanism consistent with receptor-mediated endocytosis.

Confocal microscopy images of MCF-7 cells treated with hTF conjugated to PVDMA $_{\mathrm{FC}^{-}}$ mTEG (Figure 6, row 4) exhibited punctate regions of green fluorescence throughout the cell body, similar to results observed with hTF-488. These results demonstrated successful internalization of the conjugates. A competition experiment similar to that described above for hTF-488 was performed in which cells were treated with hTF-PVDMA $\mathrm{FC}-\mathrm{mTEG}$ conjugate in the presence of 1000 -fold excess $(10 \mu \mathrm{M})$ unlabeled hTF. The green channel and merged confocal microscopy images for this experiment (Figure 6, row 5) revealed the reduction of green signal to the level of autofluorescence, indicating that the internalization of hTF-targeted protein-polymer conjugates was dependent on specific binding of hTF to TFR. Internalization of hTF-488 and of hTF-PVDMA ${ }_{F C}-m T E G$ molecules was further demonstrated by collecting a series of images from neighboring confocal planes of clusters of cells, termed z-stacks, confirming that green fluorescence was present within cells, rather than on the cell surface (Video 1 and Video 2).

We explored whether nonspecific polymer interactions substantially contributed to the binding and internalization signal we observed for hTF-PVDMA $A_{F C}-m T E G$ (Figure 7). We 
co-incubated hTF-PVDMA $\mathrm{FC}_{\mathrm{FC}}$-mTEG with an excess of unlabeled PVDMA-mTEG, and observed no noticeable reduction in signal, suggesting that nonspecific interactions of the polymer with the cell surface were not necessary for binding and internalization (Figure 7, row 1). To further confirm that specific ligand-receptor interactions were required for internalization, we examined potential binding and internalization of the negative control protein-polymer conjugate, OTF-PVDMA $\mathrm{FC}_{\mathrm{F}} \mathrm{mTEG}$, which was not expected to bind any MCF-7 cell surface receptors. OTF is a chicken transferrin, and MCF-7 cells express human TFR. We did not observe any MCF-7 cell binding or internalization of OTF protein directly labeled with AF488 (Figure 7, row 2). Similarly, we also did not observe MCF-7 cell

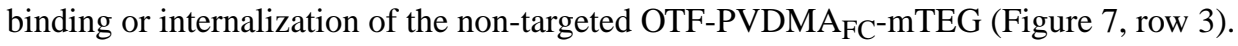
Finally, fluorescently labeled polymer not conjugated to any protein ( $\left.\mathrm{PVDMA}_{\mathrm{FC}}-\mathrm{mTEG}\right)$ did not adhere to or internalize into MCF-7 cells (Figure 7, row 4). These results provided further confirmation that hTF-PVDMA $\mathrm{FC}_{\mathrm{F}}-\mathrm{mTEG}$ conjugates were internalized via specific interactions of the hTF ligand with cell surface receptor TFR, rather than through nonspecific interactions of polymer with the cells.

When conjugating polymers to proteins, there is the risk that the polymer will destabilize the protein structure, or that the polymer will sterically block the interaction of a protein ligand with its receptor, rendering the protein-polymer conjugate irrelevant for the intended application. Importantly, the protein-polymer conjugate internalization experiments we have conducted demonstrated that hTF protein maintained its ability to bind and be internalized by TFR when conjugated to PVDMA-mTEG, suggesting that hTF maintained its structure and function when conjugated to PVDMA-mTEG.

\section{CONCLUSION}

We have developed a new, modular strategy for conjugating diverse proteins to hydrophilic polymers using the reactive, azlactone-functionalized polymer PVDMA with the goal of developing conjugates for applications in targeted drug delivery. In our approach, we first functionalized PVDMA with mTEG to render the polymer water-soluble. We demonstrated the conjugation of this reactive polymer with proteins in aqueous solution. When the targeting protein holo-transferrin was conjugated to a fluorescently labeled analogue of PVDMA-mTEG, protein-polymer conjugates were internalized into tumor cells expressing the transferrin receptor in a receptor-specific manner.

Internalization of hTF-PVDMA-mTEG conjugates into human cells expressing TFR has implications for targeted delivery to the central nervous system and to tumor cells with overexpressed receptors. ${ }^{4,56,60,66-68}$ Our approach to synthesizing protein-polymer complexes for drug delivery could be extended to encompass protein ligands that bind other receptors relevant for a variety of clinical needs to generate protein-polymer-drug conjugates for diverse targeted drug delivery applications. Although in this initial report proteins were conjugated to PVDMA through primary amines contained naturally in the native protein sequences, both the targeting protein and the polymer could be further modified for site-specific conjugation reactions. 
While the experiments described here focused on mTEG-modified PVDMA, this postpolymerization modification approach to the synthesis of multifunctional bioconjugates permits rapid and straightforward access to a broad range of macromolecular structures without requiring the synthesis of new polymers each time a new structure is to be investigated. For example, diverse side chain chemistries and degrees of functionalization can readily be explored. In addition, because the polymer modification reactions are conducted initially in organic solvents, non-water-soluble functionality, such as hydrophobic drugs, may be incorporated into the polymer prior to conjugation to the proteins. The polymer could be modified to allow release of an incorporated drug once the drug reaches its intended target. The synthetic versatility of PVDMA and the ease with which it can be conjugated to proteins offers opportunities for preparing a range of bioconjugates tailored to specific biomedical applications.

\section{EXPERIMENTAL PROCEDURES}

\section{Materials}

Triethylene glycol monomethyl ether (mTEG), 1,8-diazabicylo[5.4.0]undec-7-ene (DBU), 2,2' -azobis(2-methylpropionitrile) (AIBN), 2-(dodecylthiocarbonothioylthio)-2methylpropionic acid (DDMAT), ovotransferrin (OTF), 4-iodoanisole, and anhydrous dioxane were purchased from Sigma-Aldrich and used without further purification unless otherwise noted. The monomer 2-vinyl-4,4-dimethylazlactone (VDMA) was synthesized as previously described ${ }^{69}$ Fluorescein cadaverine (FC) was purchased from Biotium. Alexa Fluor 488 tetrafluorophenyl ester, NuPAGE 4-12\% Bis-Tris gels, MES buffer, and LDS buffer were purchased from ThermoFisher Scientific. Inhibitor removal resin was purchased from Alfa Aesar. Holo-transferrin (HTf, Cat. No. 616397) was purchased from CalBiochem. PBS (10x) was purchased from Fisher Scientific. THF was purified using alumina drying columns. All other solvents were purchased from Pharmco-AAPER (Brookfield, CT). Deuterated DMSO (DMSO- $\left.d_{6}\right)$ and deuterated chloroform $\left(\mathrm{CDCl}_{3}\right)$ were purchased from Cambridge Isotope Laboratories, Inc. Dulbecco's Modified Eagle's Medium (DMEM) was purchased from ATCC, and all other cell culture reagents were obtained from Gibco. Phalloidin conjugated to Alexa Flour 594 was purchased from Thermo Fisher, formaldehyde as a 3.7\% solution in PBS was from Fisher Scientific, and Vectashield mounting medium with DAPI was from Vector Labs.

\section{General Considerations}

${ }^{1} \mathrm{H}-\mathrm{NMR}$ spectra were collected on a Bruker $500 \mathrm{MHz}$ NMR spectrometer. Attenuated total reflectance infrared (ATR-IR) spectra were obtained using a Bruker ALPHA FTIR spectrometer and analyzed using OPUS software version 7.5. Gel permeation chromatography (GPC) was performed on an Agilent 1260 GPC instrument equipped with PLgel Mixed C and Mixed D columns and an RI detector, operating in THF at $40{ }^{\circ} \mathrm{C}$ with a flow rate of $1 \mathrm{~mL} / \mathrm{min}$. Molecular weights and dispersities were measured against polystyrene calibration standards. SEC was performed using a Superdex 75 10/300 GL column (GE) and an Agilent 1200 series liquid chromatography system. Flow cytometry was performed on a Guava easyCyte flow cytometer (Millipore-Sigma). Laser scanning confocal 
microscopy images were acquired on a Leica TCS SP5 laser scanning confocal microscope and analyzed using LAS AF software version 2.7.3.9723.

\section{Synthesis of Poly(2-vinyl-4, ' $^{\prime}$-dimethylazlactone) (PVDMA)}

VDMA was passed through a phenolic inhibitor removal resin followed by passage through a short plug of silica gel prior to polymerization. The initiator 2,2' -azobis-(isobutyronitrile) (AIBN) was recrystallized twice from methanol prior to use. AIBN $(5.9 \mathrm{mg}, 0.036 \mathrm{mmol}$, 0.5 equiv) and DDMAT ( $26 \mathrm{mg}, 0.072 \mathrm{mmol}, 1$ equiv) were weighed into a $25 \mathrm{~mL}$ Schlenk flask equipped with a stir bar. Anhydrous toluene $(4.5 \mathrm{~mL})$ was added to the flask and the mixture was stirred to dissolve the AIBN. VDMA (1.5 g, $10.8 \mathrm{mmol}, 150$ equiv) was added to the flask, and then the flask was capped with a septum and placed in a dry ice and isopropanol bath at $\sim 7$ Torr. Atmosphere was purged from the flask using three freezepump-thaw cycles and filled with nitrogen. The reaction solution was stirred at $70{ }^{\circ} \mathrm{C}$ for 12 $\mathrm{h}(\sim 85 \%$ conversion). The slightly viscous reaction mixture was cooled to room temperature and acetone $(\sim 3 \mathrm{~mL})$ was added to the flask. The polymer was precipitated twice into hexanes to yield a pale yellow solid $\left(1.26 \mathrm{~g}, 92 \%\right.$ yield). ${ }^{1} \mathrm{H} \mathrm{NMR}\left(500 \mathrm{MHz}, \mathrm{CDCl}_{3}\right): \delta=$ 1.37 (br s, $\left(-\mathrm{CH}_{3}\right)_{2}$ ), 1.62-2.1 (br m, $-\mathrm{CH}_{2} \mathrm{CH}-$ ), 2.69 (br s, $-\mathrm{CH}_{2} \mathrm{CH}-$ ). FT-IR (ATR, cm ${ }^{-1}$ ): 2980-2900 (C-H), 1820 (lactone $\left.\mathrm{C}=\mathrm{O}\right), 1672(\mathrm{C}=\mathrm{N})$. GPC: $M_{\mathrm{n}}=13.1 \mathrm{~kg} / \mathrm{mol}$; PDI = 1.35 .

\section{Synthesis of PVDMA-mTEG}

PVDMA (100 mg, $0.72 \mathrm{mmol}$ with respect to the molecular weight of the repeat unit VDMA) and mTEG ( $35 \mathrm{mg}, 0.216 \mathrm{mmol}, 0.3$ equiv) were combined in a $5 \mathrm{~mL}$ roundbottomed flask and dissolved in anhydrous THF ( $3 \mathrm{~mL})$. DBU $(16.1 \mu \mathrm{L}, 0.108 \mathrm{mmol}, 0.15$ equiv) was added to catalyze the reaction. 4-Iodoanisole ( $50.5 \mathrm{mg}, 0.216 \mathrm{mmol}, 0.3$ equiv) was added as an internal standard for determining degree of functionalization. The flask was capped with a rubber septum and purged with nitrogen for $15 \mathrm{~min}$. The reaction was stirred at $40{ }^{\circ} \mathrm{C}$ for $10 \mathrm{~h}$. Prior to purification, an aliquot $(\sim 0.2 \mathrm{~mL})$ of the reaction mixture was removed for ${ }^{1} \mathrm{H}$ NMR analysis to determine the degree of mTEG functionalization. The remaining polymer solution was purified by precipitation into diethyl ether $(100 \mathrm{~mL})$ followed by centrifugation $\left(9000 \mathrm{~g}\right.$ at $4{ }^{\circ} \mathrm{C}, 2 \mathrm{~min}$ ) to yield a yellow product. ${ }^{1} \mathrm{H}$ NMR (300 $\mathrm{MHz}, \mathrm{CDCl}_{3}$ ): $\delta=1.37-1.50$ (br m, $\left.\left(-\mathrm{CH}_{3}\right)_{2}\right), 1.62-2.1$ (br m, $-\mathrm{CH}_{2} \mathrm{CH}-$ ), 2.5 (br s, $\mathrm{CH}_{2} \mathrm{CH}-$ ), 2.84 (br s, $-\mathrm{CH}_{2} \mathrm{CH}-$ ), 3.38 (br s, $\mathrm{CH}_{3}-\mathrm{O}-$ ), 3.45-3.65 (br m, $-\mathrm{CH}_{2}-\mathrm{O}-$ ), 4.22 (br s, $\left.-\mathrm{C}(=\mathrm{O}) \mathrm{O}-\mathrm{CH}_{2}\right)$. FT-IR (ATR, $\mathrm{cm}^{-1}$ ): 2880-2900 (C-H), 1820 (lactone $\mathrm{C}=\mathrm{O}$ ), 1735 (ester $\mathrm{C}=\mathrm{O}$ ), $1672(\mathrm{C}=\mathrm{N}$ ), 1650 (amide $\mathrm{C}=\mathrm{O}$ ), 1540 (amide II $\mathrm{CN}$ and $\mathrm{NH}$ ).

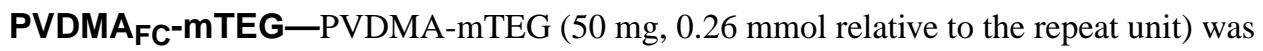
dissolved in anhydrous DMSO $(1 \mathrm{~mL})$ in a $1.5 \mathrm{~mL}$ microcentrifuge tube. Fluorescein cadaverine (FC) $(0.95 \mathrm{mg}, 1.3 \mu \mathrm{mol})$ was dissolved in anhydrous DMSO $(9.5 \mu \mathrm{L})$ and added to the polymer solution. The reaction was mixed by gentle rotation for $2 \mathrm{~h}$ at room temperature. The labeled polymer was used for protein conjugation or hydrolysis without additional purification.

Hydrolyzed PVDMA $A_{F C}-m T E G$ - Unreactive, hydrolyzed PVDMA FC -mTEG used for control experiments was synthe-sized by dissolving PVDMA $\mathrm{FC}_{\mathrm{F}}-\mathrm{mTEG}(100 \mathrm{mg})$ in DMSO 
$(2 \mathrm{~mL})$ in a $5 \mathrm{~mL}$ round-bottom flask. Water $(95.7 \mathrm{mg}, 5.32 \mathrm{mmol}, 10$ eq relative to the azlactone repeat unit) and DBU (202 $\mathrm{mg}, 1.33 \mathrm{mmol}, 2.5$ eq relative to the azlactone repeat unit) were added and the solution was allowed to react at $40{ }^{\circ} \mathrm{C}$ for $3 \mathrm{~h}$. Complete hydrolysis was confirmed using ATR-FTIR spectroscopy. Samples were then dialyzed against PBS for $24 \mathrm{~h}(\mathrm{MWCO}=3.5 \mathrm{kDa})$ to remove any small-molecule impurities, including unreacted fluorophore, prior to incubation with cells. FT-IR (ATR, $\left.\mathrm{cm}^{-1}\right)$ : 3500-2600 (O-H), 2880$2900(\mathrm{C}-\mathrm{H}), 1725$ (carboxylic acid $\mathrm{C}=\mathrm{O}$ ), 1650 (amide $\mathrm{C}=\mathrm{O}$ ), 1540 (amide II $\mathrm{CN}$ and $\mathrm{NH})$.

\section{PVDMA-mTEG Hydrolysis Study}

PVDMA-mTEG (244 mg, $1.32 \mathrm{mmol}$ relative to the repeat unit) was dissolved in anhydrous DMSO $(4.9 \mathrm{~mL})$. PBS $(11 \mathrm{~mL})$ was added to simulate the concentration of polymer used in a 1:50 molar ratio conjugation of hTF to polymer. At each time point $(0.5,1,3,5,9,12$, and $24 \mathrm{~h}$ ), a $1 \mathrm{~mL}$ sample (15.3 mg of polymer) was flash frozen in liquid nitrogen and freezedried. The samples were dissolved in acetone and cast directly onto the ATR crystal for analysis by FT-IR spectroscopy.

\section{Synthesis of Protein-Polymer Conjugates}

Proteins (i.e., hTF and OTF) were conjugated to polymer using the following general procedure. Protein stock solutions of $1 \mathrm{mg} / \mathrm{mL}$ were prepared in PBS with $0.1 \mathrm{M}$ sodium bicarbonate $(\mathrm{pH}=8.0)$, to increase the reactivity of the primary amines of the protein. Polymer samples (i.e., PVDMA-mTEG or PVDMA $\left.{ }_{\mathrm{FC}}-\mathrm{mTEG}\right)(50 \mathrm{mg})$ were dissolved in DMSO $(1 \mathrm{~mL})$ in a microcentrifuge tube. A $1 \mathrm{~mL}$ aliquot of the desired protein $(1 \mathrm{mg})$ was added to polymer solution to achieve a protein:polymer molar ratio of 1:50, where a mole of polymer was calculated using data from GPC analysis. The molecular weight of a monomer of VDMA is $139 \mathrm{~g} / \mathrm{mol}$. Therefore, a molar ratio of $1 \mathrm{~mol}$ protein: $50 \mathrm{~mol}$ polymer is equivalent to a molar ratio of $1 \mathrm{~mol}$ protein: $241 \mathrm{~mol}$ VDMA monomer. For studies examining the effect on conjugation of the molar ratio of protein:polymer molecules, ratios of 1:5, 1:10, 1:20, and 1:50 were compared. The samples were reacted at $4{ }^{\circ} \mathrm{C}$ with gentle rotation overnight. Samples were then dialyzed against PBS for $24 \mathrm{~h}(\mathrm{MWCO}=3.5 \mathrm{kDa})$ to remove any small-molecule impurities, including unreacted fluorophore, if the sample was not being purified by SEC.

\section{Analysis of Protein-Polymer Conjugates by SDSPAGE}

Sodium dodecyl sulfate-polyacrylamide gel electrophoresis (SDS-PAGE) was used to analyze conjugation of protein to polymers. NuPAGE LDS buffer $(4 \times)$ was added to each sample to a final concentration of $1 \times$, without reducing agent. All proteins studied contain disulfide bonds, and therefore the absence of reducing agents can shift their apparent molecular weight from the predicted molecular weight. The samples were heated in a water bath for $10 \mathrm{~min}$ at $70{ }^{\circ} \mathrm{C}$ to denature the proteins. Samples were loaded onto a NuPAGE 4$12 \%$ Bis-Tris gel. The gel was run in NuPAGE MES running buffer $(1 \times)$. Gels were then stained with Simply Blue Safe Stain. 


\section{Protein-Polymer Conjugate Purification}

Protein-polymer conjugation reactions were first concentrated and purified from low molecular weight species using a centrifugal filtration device with a MWCO of $10 \mathrm{kDa}$ (EMD Millipore) and extensive washing with PBS. The protein-polymer conjugation reaction was then purified by SEC on a Superdex 75 10/300 column (GE Healthcare Life Sciences), using PBS as the eluent. Fractions of interest were pooled and concentrated with a centrifugal filtration device with a MWCO of $10 \mathrm{kDa}$. All samples were analyzed by SDSPAGE and imaged on a BioRad ChemiDoc MP imaging system using Image Lab 6.0 software (BioRad).

\section{Cells, Cell Culture, and Receptor Detection}

The MCF7 human breast cancer cell line (ATCC HTB-22, acquired in 2018) was used to test internalization of protein-polymer conjugates via receptor-mediated endocytosis of TFR. MCF-7 cells were cultured at $37{ }^{\circ} \mathrm{C}$ in a humidified atmosphere with $5 \% \mathrm{CO}_{2}$ in DMEM with $10 \%$ fetal bovine serum, $100 \mathrm{U} / \mathrm{mL}$ penicillin, and $100 \mu \mathrm{g} / \mathrm{mL}$ streptomycin. Cells were subcultured after reaching $80 \%$ confluency using $0.25 \%$ trypsin-EDTA. The presence of human TFR on the surface of MCF-7 cells was confirmed with an anti-human TFR antibody directly labeled with fluorescein isothiocyanate (antibody clone CY1G4, from BioLegend, Cat. No. 334103). MCF-7 cells were harvested with $0.05 \%$ trypsin-EDTA. A total of $1 \times 10^{6}$ cells were incubated with antibody at a 1:20 dilution in PBS with $0.1 \%$ bovine serum albumin (PBSA) for $30 \mathrm{~min}$ at room temperature with gentle rotation. Cells were washed with PBSA to remove unbound antibody, resuspended in PBSA, and analyzed by flow cytometry.

\section{Internalization Assays and Confocal Microscopy}

MCF-7 cells were seeded in a four-well Millipore EZ chamber slide using $4 \times 10^{4}$ cells/well and allowed to establish adherence and reach $50-80 \%$ confluency. The media was then replaced with serum-free DMEM containing the specified conjugate sample in a $500 \mu \mathrm{L}$ total volume. hTF-488, hTF-PVDMA ${ }_{\mathrm{FC}}$-mTEG, OTF-488, or OTF-PVDMA $\mathrm{FC}$-mTEG were added to the wells to a final concentration equivalent to $10 \mathrm{nM}$ of protein per well. For the internalization sample with hydrolyzed $\mathrm{PVDMA} \mathrm{FC}_{\mathrm{FC}}$ that was not conjugated to protein, an amount of polymer equivalent to the amount of polymer in $10 \mathrm{nM}$ of protein-polymer conjugate was used, as determined by measurement of samples by UV-vis spectroscopy, using absorbance at $494 \mathrm{~nm}$ due to the presence of fluorophore. For competition experiments with unlabeled hTF, $10 \mu \mathrm{M}$ unlabeled hTF was included. For the competition experiment with excess unlabeled polymer, $0.5 \mathrm{mg}$ of hydrolyzed PVDMA-mTEG was included. Samples were incubated for $1 \mathrm{~h}$ at $37{ }^{\circ} \mathrm{C}$ in a humidified environment with $5 \% \mathrm{CO}_{2}$. Media with samples were removed, and cells were washed with PBS. Cells were fixed with $3.7 \%$ formaldehyde for 5-10 min at room temperature and washed with PBS. Cells were permeabilized by incubation with $0.1 \%$ Triton-X 100 in PBS at room temperature for $5 \mathrm{~min}$ and washed with PBS. Actin filaments were stained with an Alexa Fluor 594 conjugate of phalloidin to help identify cell boundaries by adding $250 \mu \mathrm{L}$ per well of phalloidin in PBS diluted following manufacturer's protocol, and cells were washed with PBS. Wells were removed from the slide and Vectashield mounting media containing DAPI for staining cell 
nuclei was applied to the fixed samples. Samples were then covered with $1.5 \mathrm{~mm}$ glass coverslips and sealed with transparent nail polish. Samples were imaged using a $63 \times$ oil immersion objective. Images were collected using sequential scanning, and an overlay of the sequential images was used to analyze internalization, for single focal plane images and for z-stacks collected as a series of neighboring focal planes.

\section{Supplementary Material}

Refer to Web version on PubMed Central for supplementary material.

\section{ACKNOWLEDGMENTS}

This work was funded by Smith College new faculty funding to S.J.M. and to M.E.B. J.S.K. received a Katherine C. Hauch 1921 Fund Undergraduate Research Fellowship, and A.V.C. received a Schultz Foundation Undergraduate Research Fellowship. J.S.K., A.V.C., and E.J. received support from the Nancy Kershaw Tomlinson Memorial Fund at Smith College. This work was supported by the National Institutes of Health/National Cancer Institute (R15CA198927-01 to S.J.M). We thank Lou Ann Bierwert, Director for the Smith College Center for Molecular Biology; Judith Wopereis, Director for the Smith College Center for Microscopy and Imaging; and Kalina Dimova, Technical Director of the Smith College Center for Proteomics for expert insight and technical assistance. We thank Krystal Cogar and Stephen Rosa in the Department of Polymer Science and Engineering at the University of Massachusetts Amherst for running all GPC samples. We acknowledge Anne Mason at the University of Vermont for insightful discussions, and Michael Kinsinger at Smith College and Patrick Flaherty at the University of Massachusetts for helpful discussions and critical reading of the manuscript.

\section{ABBREVIATIONS}

$\begin{array}{ll}\text { AIBN } & 2,2^{\prime} \text {-azobis(2-methylpropionitrile) } \\ \text { BBB } & \text { blood-brain barrier } \\ \text { FC } & \text { fluorescein cadaverine } \\ \text { hTF } & \text { holo-transferrin } \\ \text { hTF-488 } & \text { holo-transferrin labeled with Alexa Fluor } 488 \\ \text { mTEG } & \text { triethylene glycol monomethyl ether } \\ \text { MWCO } & \text { molecular weight cutoff } \\ \text { OTF } & \text { ovotransferrin } \\ \text { OTF-488 } & \text { ovotransferrin labeled with Alexa Fluor } 488 \\ \text { PEG } & \text { polyethylene glycol } \\ \text { PVDMA } & \text { poly(2-vinyl-4,4-dimethylazlactone) } \\ \text { RAFT } & \text { reversible addition-fragmentation transfer } \\ \text { RMT } & \text { receptor-mediated transcytosis } \\ \text { TFR } & \begin{array}{l}\text { transferrin receptor } \\ \text { VDMA }\end{array}\end{array}$




\section{REFERENCES}

(1). Chen Y, and Liu L (2012) Modern methods for delivery of drugs across the blood-brain barrier. Adv. Drug Delivery Rev 64, 640-665.

(2). Patel MM, and Patel BM (2017) Crossing the Blood-Brain Barrier: Recent Advances in Drug Delivery to the Brain. CNS Drugs 31, 109-133. [PubMed: 28101766]

(3). Mikitsh JL, and Chacko A-M (2014) Pathways for Small Molecule Delivery to the Central Nervous System across the Blood-Brain Barrier. Perspect. Med. Chem 6, PMC.S13384.

(4). Lajoie JM, and Shusta EV (2015) Targeting Receptor-Mediated Transport for Delivery of Biologics Across the Blood-Brain Barrier. Annu. Rev. Pharmacol. Toxicol 55, 613-631. [PubMed: 25340933]

(5). Pardridge WM, and Boado RJ (2012) Reengineering Biopharmaceuticals for Targeted Delivery Across the Blood-Brain Barrier. Methods Enzymol. 503, 269-292. [PubMed: 22230573]

(6). Giugliani R, Giugliani L, Corte AD, Poswar F, Donis K, Schmidt M, Hunt D, Boado RJ, and Pardridge WM (2018) Safety and clinical efficacy of AGT-181, a brain penetrating human insulin receptor antibody-iduronidase fusion protein, in a 26-week study with pediatric patients with mucopolysaccharidosis type I. Mol. Genet. Metab 123, S54.

(7). Bae YH, and Park K (2011) Targeted drug delivery to tumors: Myths, reality and possibility. J. Controlled Release 153, 198-205.

(8). Gordon MR, Canakci M, Li L, Zhuang J, Osborne B, and Thayumanavan S (2015) Field Guide to Challenges and Opportunities in Antibody-Drug Conjugates for Chemists. Bioconjugate Chem. 26, 2198-2215.

(9). Perez HL, Cardarelli PM, Deshpande S, Gangwar S, Schroeder GM, Vite GD, and Borzilleri RM (2014) Antibody-drug conjugates: current status and future directions. Drug Discovery Today 19, 869-881. [PubMed: 24239727]

(10). Dan N, Setua S, Kashyap VK, Khan S, Jaggi M, Yallapu M, and Chauhan S (2018) AntibodyDrug Conjugates for Cancer Therapy: Chemistry to Clinical Implications. Pharmaceuticals 11, 32.

(11). Bobo D, Robinson KJ, Islam J, Thurecht KJ, and Corrie SR (2016) Nanoparticle-Based Medicines: A Review of FDA-Approved Materials and Clinical Trials to Date. Pharm. Res 33, 2373-2387. [PubMed: 27299311]

(12). Rosenblum D, Joshi N, Tao W, Karp JM, and Peer D (2018) Progress and challenges towards targeted delivery of cancer therapeutics. Nat. Commun 9, 1410. [PubMed: 29650952]

(13). Carter PJ (2011) Introduction to current and future protein therapeutics: A protein engineering perspective. Exp. Cell Res 317, 1261-1269. [PubMed: 21371474]

(14). Kariolis MS, Kapur S, and Cochran JR (2013) Beyond antibodies: using biological principles to guide the development of next-generation protein therapeutics. Curr. Opin. Biotechnol 24, 10721077. [PubMed: 23587963]

(15). Kinch MS (2015) An overview of FDA-approved biologics medicines. Drug Discovery Today 20, 393-398. [PubMed: 25220442]

(16). Rodgers KR, and Chou RC (2016) Therapeutic monoclonal antibodies and derivatives: Historical perspectives and future directions. Biotechnol. Adv 34, 1149-1158. [PubMed: 27460206]

(17). Qi Y, and Chilkoti A (2015) Protein-polymer conjugation-moving beyond PEGylation. Curr. Opin. Chem. Biol 28, 181-193. [PubMed: 26356631]

(18). Pelegri-O'Day EM, Lin E-W, and Maynard HD (2014) Therapeutic Protein-Polymer Conjugates: Advancing Beyond PEGy-lation. J. Am. Chem. Soc 136, 14323-14332. [PubMed: 25216406]

(19). Russell AJ, Baker SL, Colina CM, Figg CA, Kaar JL, Matyjaszewski K, Simakova A, and Sumerlin BS (2018) Next generation protein-polymer conjugates. AIChE J. 64, 3230.

(20). Pasut G, and Veronese FM (2012) State of the art in PEGylation: The great versatility achieved after forty years of research. J. Controlled Release 161, 461-472.

(21). Alconcel SNS, Baas AS, and Maynard HD (2011) FDA-approved poly(ethylene glycol)-protein conjugate drugs. Polym. Chem 2, 1442-1448. 
(22). Jevsevar S, Kunstelj M, and Porekar VG (2010) PEGylation of therapeutic proteins. Biotechnol. J 5, 113-128. [PubMed: 20069580]

(23). Schellekens H, Hennink WE, and Brinks V (2013) The Immunogenicity of Polyethylene Glycol: Facts and Fiction. Pharm. Res 30, 1729-1734. [PubMed: 23673554]

(24). Zhao W, Liu F, Chen Y, Bai J, and Gao W (2015) Synthesis of well-defined protein-polymer conjugates for biomedicine. Polymer 66, A1-A10.

(25). Broyer RM, Grover GN, and Maynard HD (2011) Emerging synthetic approaches for proteinpolymer conjugations. Chem. Commun. 47, 2212-2216.

(26). Pelegri-O'Day EM, and Maynard HD (2016) Controlled Radical Polymerization as an Enabling Approach for the Next Generation of Protein-Polymer Conjugates. Acc. Chem. Res 49, 17771785. [PubMed: 27588677]

(27). Baslé E, Joubert N, and Pucheault M (2010) Proteiń Chemical Modification on Endogenous Amino Acids. Chem. Biol 17, 213-227. [PubMed: 20338513]

(28). Cobo I, Li M, Sumerlin BS, and Perrier S (2015) Smart hybrid materials by conjugation of responsive polymers to biomacromolecules. Nat. Mater 14, 143-159. [PubMed: 25401924]

(29). Murata H, Carmali S, Baker SL, Matyjaszewski K, and Russell AJ (2018) Solid-phase synthesis of protein-polymers on reversible immobilization supports. Nat. Commun 9, 845. [PubMed: 29487296]

(30). Plaks JG, Falatach R, Kastantin M, Berberich JA, and Kaar JL (2015) Multisite Clickable Modification of Proteins Using Lipoic Acid Ligase. Bioconjugate Chem. 26, 1104-1112.

(31). Qi Y, Amiram M, Gao W, McCafferty DG, and Chilkoti A (2013) Sortase-Catalyzed Initiator Attachment Enables High Yield Growth of a Stealth Polymer from the C Terminus of a Protein. Macromol. Rapid Commun 34, 1256-1260. [PubMed: 23836349]

(32). Krall N, da Cruz FP, Boutureira O, and Bernardes GJL (2016) Site-selective protein-modification chemistry for basic biology and drug development. Nat. Chem 8, 103-113. [PubMed: 26791892]

(33). Peeler JC, Woodman BF, Averick S, Miyake-Stoner SJ, Stokes AL, Hess KR, Matyjaszewski K, and Mehl RA (2010) Genetically Encoded Initiator for Polymer Growth from Proteins. J. Am. Chem. Soc 132, 13575-13577. [PubMed: 20839808]

(34). Wang Y, and Wu C (2018) Site-Specific Conjugation of Polymers to Proteins. Biomacromolecules 19, 1804-1825. [PubMed: 29722971]

(35). Le Droumaguet B, and Nicolas J (2010) Recent advances in the design of bioconjugates from controlled/living radical polymerization. Polym. Chem 1, 563.

(36). Paeth M, Stapleton J, Dougherty ML, Fischesser H, Shepherd J, McCauley M, Falatach R, Page RC, Berberich JA, and Konkolewicz D (2017) Approaches for Conjugating Tailor-Made Polymers to Proteins. Methods Enzymol. 590, 193-224. [PubMed: 28411638]

(37). Isarov SA, Lee PW, and Pokorski JK (2016) “Graft-to" Protein/Polymer Conjugates Using Polynorbornene Block Copolymers. Biomacromolecules 17, 641-648. [PubMed: 26765848]

(38). Jones MW, Strickland RA, Schumacher FF, Caddick S, Baker JR, Gibson MI, and Haddleton DM (2012) Polymeric Dibromomaleimides As Extremely Efficient Disulfide Bridging Bioconjugation and Pegylation Agents. J. Am. Chem. Soc 134, 1847-1852. [PubMed: 22188166]

(39). Hall DJ, Van den Berghe HM, and Dove AP (2011) Synthesis and post-polymerization modification of maleimide-containing polymers by 'thiol-ene' click and Diels-Alder chemistries. Polym. Int 60, 1149-1157.

(40). Alvaradejo GG, Glassner M, Hoogenboom R, and Delaittre G (2018) Maleimide endfunctionalized poly(2-oxazoline)s by the functional initiator route: synthesis and (bio) conjugation. RSC Adv. 8, 9471-9479.

(41). Moatsou D, Li J, Ranji A, Pitto-Barry A, Ntai I, Jewett MC, and O’Reilly RK (2015) SelfAssembly of Temperature-Responsive Protein-Polymer Bioconjugates. Bioconjugate Chem. 26, 1890-1899.

(42). Das A, and Theato P (2016) Activated Ester Containing Polymers: Opportunities and Challenges for the Design of Functional Macromolecules. Chem. Rev 116, 1434-1495. [PubMed: 26305991]

(43). Jones W, Richards M, Haddleton S-JM, and Gibson DI (2013) Poly(azlactone)s: versatile scaffolds for tandem post-polymerisation modification and glycopolymer synthesis. Polym. Chem 4, 717-723. 
(44). Gauthier MA, Gibson MI, and Klok H-A (2009) Synthesis of Functional Polymers by PostPolymerization Modification. Angew. Chem., Int. Ed 48, 48-58.

(45). Buck ME, and Lynn DM (2012) Azlactone -functionalized polymers as reactive platforms for the design of advanced materials: Progress in the last ten years. Polym. Chem 3, 66-80. [PubMed: 29492112]

(46). Zhong Y, Zeberl BJ, Wang X, and Luo J (2018) Combinatorial approaches in post-polymerization modification for rational development of therapeutic delivery systems. Acta Biomater. 73, 21-37. [PubMed: 29654990]

(47). Ho HT, Levere ME, Fournier D, Montembault V, Pascual S, and Fontaine L (2012) Introducing the Azlactone Functionality into Polymers through Controlled Radical Polymerization: Strategies and Recent Developments. Aust. J. Chem 65, 970-977.

(48). Ho HT, Levere ME, Pascual S, Montembault V, Casse N, Caruso A, and Fontaine L (2013) Thermoresponsive block copolymers containing reactive azlactone groups and their bioconjugation with lysozyme. Polym. Chem 4, 675-685.

(49). Pascual S, Blin T, Saikia PJ, Thomas M, Gosselin P, and Fontaine L (2010) Block copolymers based on 2-vinyl-4, 4-dimethyl-5-oxazolone by RAFT polymerization: Experimental and computational studies. J. Polym. Sci., Part A: Polym. Chem 48, 5053-5062.

(50). Speetjens FW, Carter MCD, Kim M, Gopalan P, Mahanthappa MK, and Lynn DM (2014) PostFabrication Placement of Arbitrary Chemical Functionality on Microphase-Separated Thin Films of Amine-Reactive Block Copolymers. ACS Macro Lett. 3, 1178-1182.

(51). Heilmann SM, Rasmussen JK, and Krepski LR (2001) Chemistry and technology of 2-alkenyl azlactones. J. Polym. Sci., Part A: Polym. Chem 39, 3655-3677.

(52). Delplace V, Harrisson S, Ho HT, Tardy A, Guillaneuf Y, Pascual S, Fontaine L, and Nicolas J (2015) One-Step Synthesis of Azlactone-Functionalized SG1-Based Alkoxyamine for NitroxideMediated Polymerization and Bioconjugation. Macromolecules 48, 2087-2097.

(53). Weeks CA, Aden B, Kilbey SM, and Janorkar AV (2016) Synthesis and Characterization of an Array of Elastin-like Polypeptide-Polyelectrolyte Conjugates with Varying Chemistries and Amine Content for Biomedical Applications. ACS Biomater. Sci. Eng 2, 2196-2206.

(54). Gardner CM, Brown CE, and Stöver HDH (2012) Synthesis and properties of water-soluble azlactone copolymers. J. Polym. Sci., Part A: Polym. Chem 50, 4674-4685.

(55). Zhu Y, Quek JY, Lowe AB, and Roth PJ (2013) Thermoresponsive (Co)polymers through Postpolymerization Modification of Poly(2-vinyl-4, 4-dimethylazlactone). Macromolecules 46, 6475-6484.

(56). Luck AN, and Mason AB (2013) Structure and dynamics of drug carriers and their interaction with cellular receptors: Focus on serum transferrin. Adv. Drug Delivery Rev. 65, 1012-1019.

(57). Wong ASM, Czuba E, Chen MZ, Yuen D, Cupic KI, Yang S, Hodgetts RY, Selby LI, Johnston APR, and Such GK (2017) pH-Responsive Transferrin-pHlexi Particles Capable of Targeting Cells in Vitro. ACS Macro Lett. 6, 315-320.

(58). Carter MCD, Jennings J, Speetjens FW, Lynn DM, and Mahanthappa MK (2016) A Reactive Platform Approach for the Rapid Synthesis and Discovery of High $\chi /$ Low N Block Polymers. Macromolecules 49, 6268-6276.

(59). Paterson J, and Webster CI (2016) Exploiting transferrin receptor for delivering drugs across the blood-brain barrier. Drug Discovery Today: Technol. 20, 49-52.

(60). Daniels TR, Bernabeu E, Rodríguez JA, Patel S, Kozman M, Chiappetta DA, Holler E, Ljubimova JY, Helguera G, and Penichet ML (2012) The transferrin receptor and the targeted delivery of therapeutic agents against cancer. Biochim. Biophys. Acta, Gen. Subj 1820, 291-317.

(61). Jiang Y, Liang M, Svejkar D, Hart-Smith G, Lu H, Scarano W, and Stenzel MH (2014) Albuminmicelles via a one-pot technology platform for the delivery of drugs. Chem. Commun 50, 63946397.

(62). Leverence R, Mason AB, and Kaltashov IA (2010) Noncanonical interactions between serum transferrin and transferrin receptor evaluated with electrospray ionization mass spectrometry. Proc. Natl. Acad. Sci. U. S. A 107, 8123-8128. [PubMed: 20404192]

(63). Vandewalle B, Granier AM, Peyrat JP, Bonneterre J, and Lefebvre J (1986) Detection of Transferrin Receptors in Cultured Breast Cancer Cells. Ann. N. Y. Acad. Sci 464, 482-485. 
(64). Tortorella S, and Karagiannis TC (2014) Transferrin Receptor-Mediated Endocytosis: A Useful Target for Cancer Therapy. J. Membr. Biol 247, 291-307. [PubMed: 24573305]

(65). Lim C-J, Norouziyan F, and Shen W-C (2007) Accumulation of transferrin in Caco-2 cells: A possible mechanism of intestinal transferrin absorption. J. Controlled Release 122, 393-398.

(66). Pardridge W (2015) Targeted delivery of protein and gene medicines through the blood-brain barrier. Clin. Pharmacol. Ther 97, 347-361. [PubMed: 25669455]

(67). Goulatis LI, and Shusta EV (2017) Protein engineering approaches for regulating blood-brain barrier transcytosis. Curr. Opin. Struct. Biol 45, 109-115. [PubMed: 28040636]

(68). Yu YJ, Atwal JK, Zhang Y, Tong RK, Wildsmith KR, Tan C, Bien-Ly N, Hersom M, Maloney JA, Meilandt WJ, et al. (2014) Therapeutic bispecific antibodies cross the blood-brain barrier in nonhuman primates. Sci. Transl. Med 6, 261ra154-261ra154.

(69). Wancura MM, Anex-Ries Q, Carroll AL, Garcia AP, Hindocha P, and Buck ME (2017) Fabrication, chemical modification, and topographical patterning of reactive gels assembled from azlactone-functionalized polymers and a diamine. J. Polym. Sci., Part A: Polym. Chem 55, 31853194. 


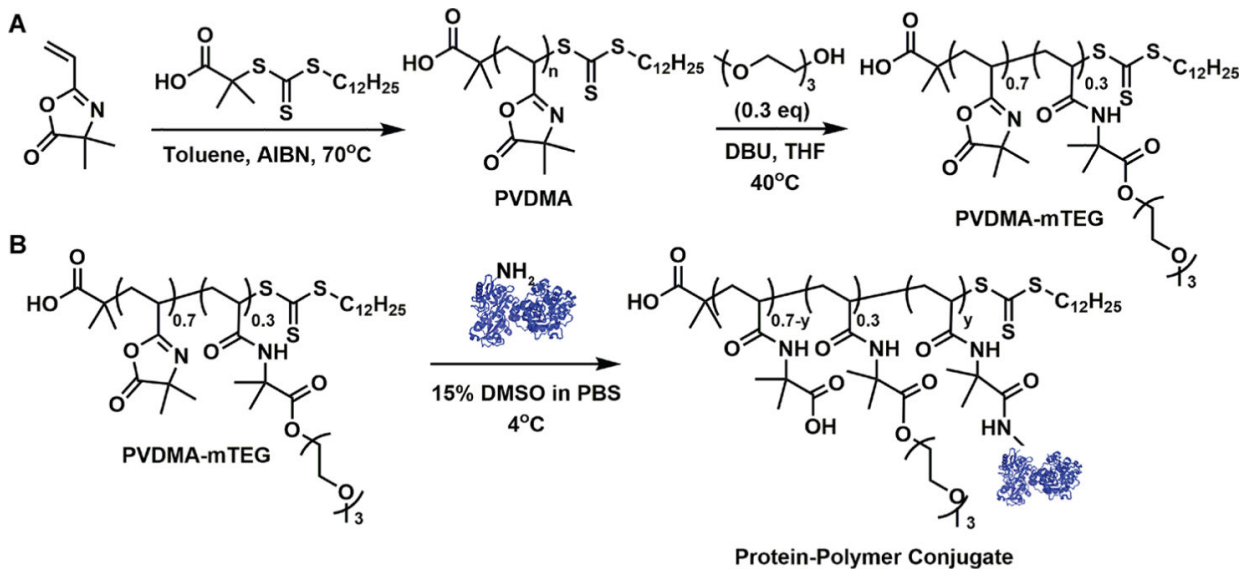

Figure 1.

Synthesis of protein-polymer conjugates via a modular grafting-to approach using watersoluble, azlactone-functionalized polymers. (A) PVDMA was synthesized by RAFT polymerization and functionalized post-polymerization with a substoichiometric equivalent of mTEG ( 0.3 molar equiv relative to repeat unit) to make the polymer soluble in water (PVDMA-mTEG). The mTEG functional groups are expected to distribute randomly throughout the polymer chain. (B) PVDMA-mTEG can be subsequently grafted to a protein, including holo-transferrin shown here (PDB 3V83). 

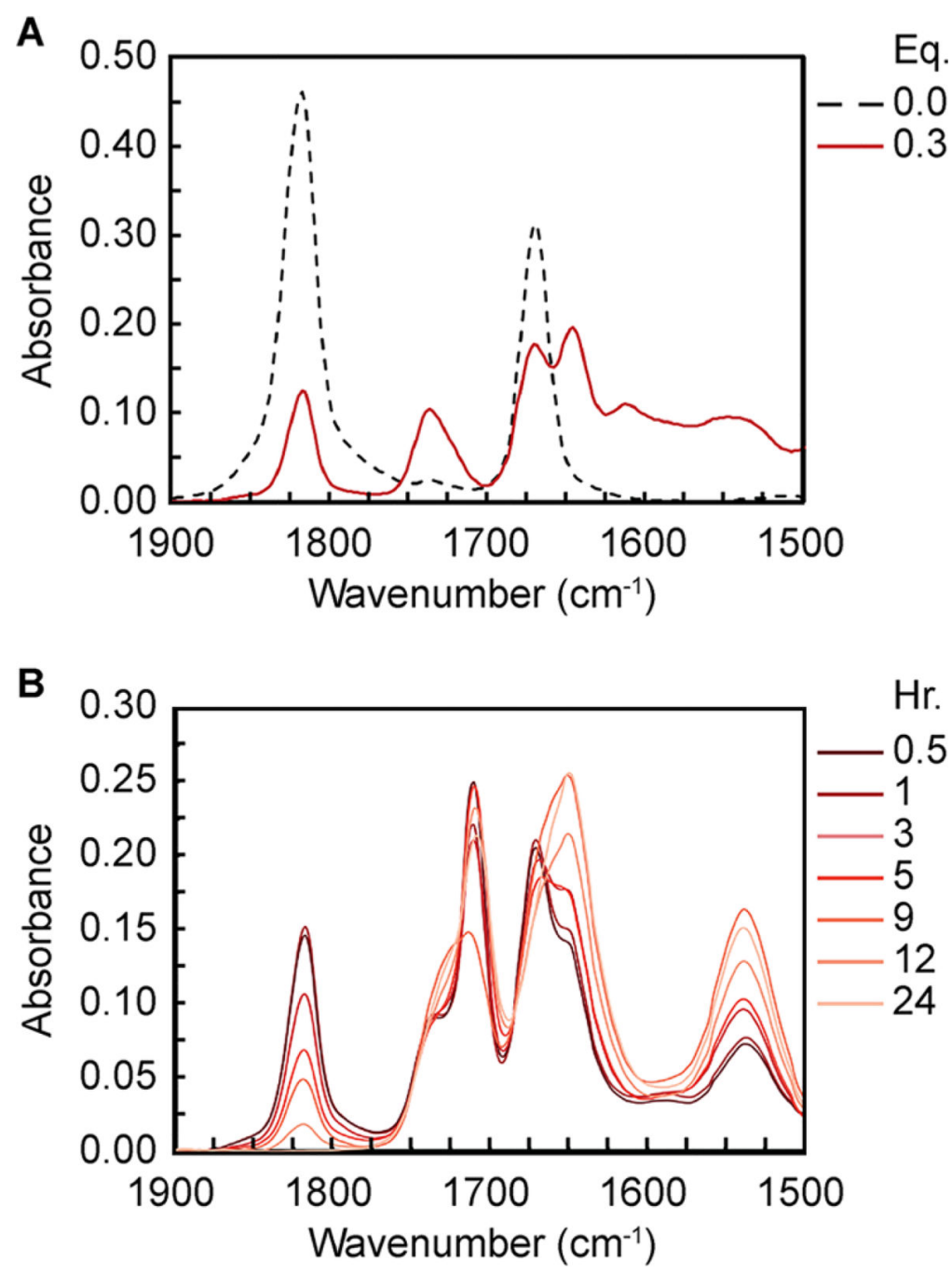

Figure 2.

Water-soluble, azlactone-functionalized copolymers can be synthesized by postpolymerization modification of PVDMA. (A) FT-IR spectra of PVDMA (black dashed curve) and PVDMA modified with 0.3 molar equivalents (Eq.) of mTEG relative to the repeat unit (red curve). The peaks at $1820 \mathrm{~cm}^{-1}$ (carbonyl) and $1670 \mathrm{~cm}^{-1}$ (imine) are characteristic of the azlactone ring. Ring opening of the lactone with an alcohol nucleophile resulted in the disappearance of the azlactone peaks and the appearance of ester $(1720 \mathrm{~cm}$ ${ }^{-1}$ ), amide I $\left(1650 \mathrm{~cm}^{-1}\right)$, and amide II $\left(1540 \mathrm{~cm}^{-1}\right)$ peaks. (B) FT-IR spectra as a function of time of PVDMA-mTEG incubation in water. FT-IR spectra revealed the disappearance of the azlactone carbonyl $\left(1820 \mathrm{~cm}^{-1}\right)$ peak and an increase in the peaks at $1735 \mathrm{~cm}^{-1}(\mathrm{ester}+$ carboxylic acid carbonyl), $1650 \mathrm{~cm}^{-1}$ (amide I), and $1540 \mathrm{~cm}^{-1}$ (amide II). The strong peak at $1710 \mathrm{~cm}^{-1}$ corresponds to acetone, which was used to cast the polymer film on the ATR crystal. The legend refers to time in hours following dissolution of PVDMA-mTEG in water. 


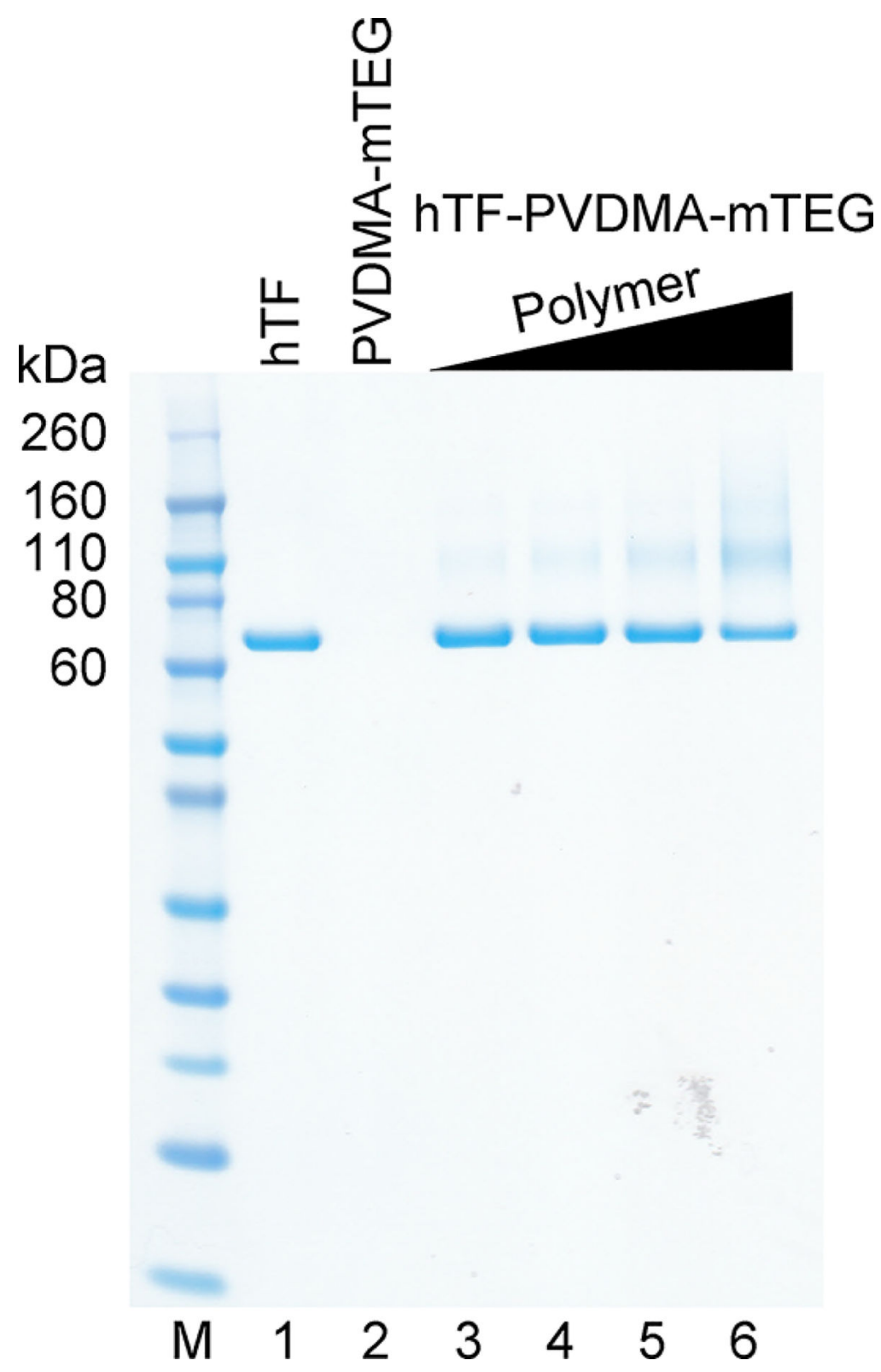

Figure 3.

Protein hTF conjugates to PVDMA-mTEG. Holotransferrin (hTF) conjugated to PVDMAmTEG in aqueous solution. The appearance of higher molecular weight bands and decrease in intensity of primary protein band indicated protein conjugation to polymer. Protein amounts in each lane were held constant. Lane 1 contained protein only, and lane 2 contained PVDMA-mTEG only. Lanes 3-6 contained unpurified protein-polymer conjugation reactions with increasing amounts of polymer relative to protein, keeping the amount of protein constant. Molar ratios of protein to polymer molecules in reactions: lane 3 $=1: 5$; lane $4=1: 10$; lane $5=1: 20$; lane $6=1: 50$. Samples were not reduced. Apparent molecular weights of the two protein-polymer conjugate bands were most consistent with protein:polymer conjugate ratios of $1: 1$ and $1: 2$. 


\section{A}

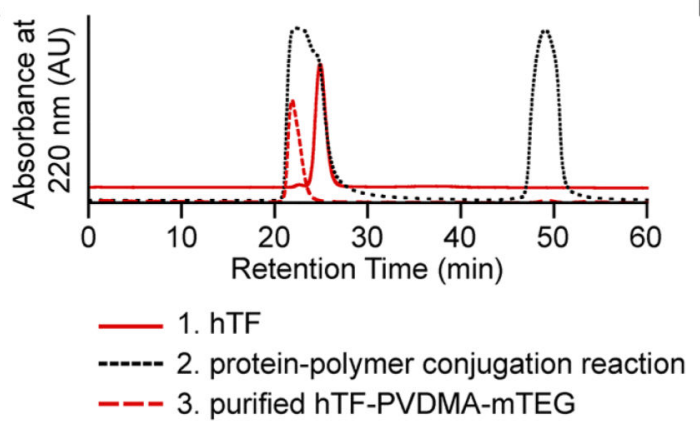

B

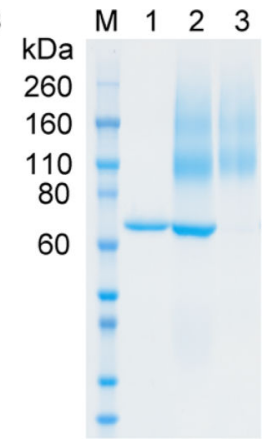

Figure 4.

Purification of hTF-PVDMA-mTEG conjugates. (A) SEC was used to analyze and purify hTF-PVDMA-mTEG conjugates from unreacted hTF and from unreacted PVDMA-mTEG. Larger molecules have a shorter retention time. Pure hTF protein (red solid line) exhibited a single narrow peak for absorbance at $220 \mathrm{~nm}$. The protein-polymer conjugation reaction (black dashed line) had overlapping peaks that included an unreacted hTF peak and a new larger molecule with shorter retention time consistent with protein-polymer conjugates, as well as a low molecular weight peak from polymer byproducts. There were no peaks in the conjugation reaction that eluted $<20 \mathrm{~min}$, indicating the absence of higher order proteinpolymer aggregates. Following collection of the protein-polymer conjugate peak and reinjection onto SEC, a narrow peak was observed as purified hTF-PVDMA-mTEG (red dashed line). PBS was the eluent for all samples. (B) SDS-PAGE analysis of hTF (lane 1), protein-polymer conjugation reaction before purification (lane 2), and SEC purified hTFPVDMA-mTEG conjugate (lane 3) demonstrated successful purification of conjugates using SEC. In the purified product (lane 3), unreacted hTF was absent. Polymers are at lower molecular weight than hTF and should therefore also be removed by SEC purification. Molecular weights of purified conjugates were consistent with protein:polymer ratios of 1:1 and 1:2. Samples were not reduced. 

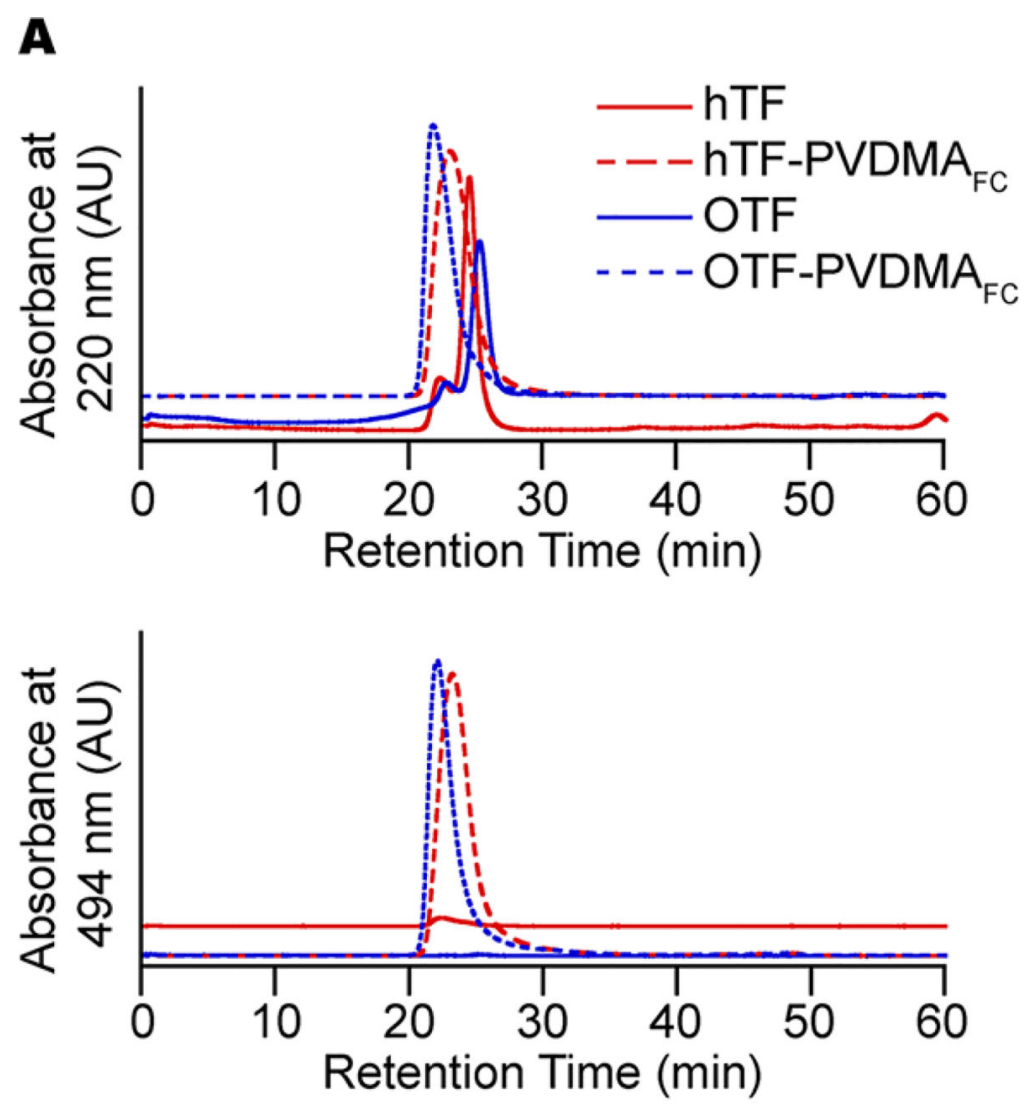

\section{B}

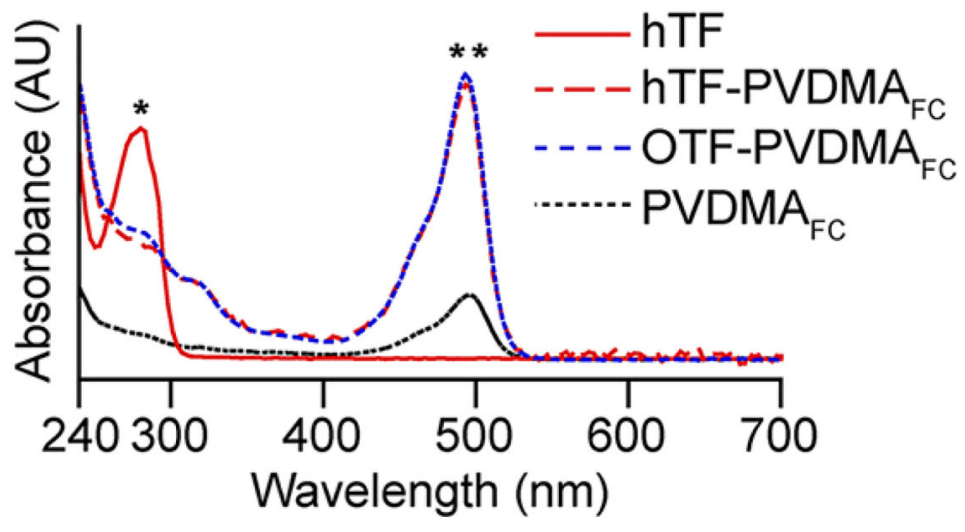

Figure 5.

Fluorescent small molecule can be coupled to polymer and protein-polymer conjugates. Small-molecule fluorophore fluorescein cadaverine (FC) was conjugated to PVDMAmTEG, and the resulting PVDMA FC $-\mathrm{mTEG}_{\text {was }}$ conjugated to hTF or OTF. (A) SEC was used to purify and analyze hTF-PVDMA $\mathrm{FC}-\mathrm{mTEG}$ and OTF-PVDMA $\mathrm{AC}_{\mathrm{FC}}-\mathrm{mTEG}_{\mathrm{T}}$ conjugates from unreacted component molecules. A single peak for hTF-PVDMA $A_{F C}$ and for OTFPVDMA $_{\mathrm{FC}}$ with retention time shorter than for the corresponding protein alone, and with absorbance at $220 \mathrm{~nm}$ (top) and for $494 \mathrm{~nm}$ (bottom), demonstrated smallmolecule fluorophore incorporation into the purified protein-polymer conjugates. Protein alone does 
not absorb at $494 \mathrm{~nm}$. The FC molecule absorbs at $494 \mathrm{~nm}$. PBS was the eluent for all samples. (B) UV-vis absorption spectra for hTF protein, PVDMA $\mathrm{FC}_{-}-\mathrm{mTEG}$, purified hTFPVDMA $_{\mathrm{FC}}-\mathrm{mTEG}$, and purified OTF-PVDMA $\mathrm{FC}-\mathrm{mTEG}$. The characteristic absorption peaks for protein $(*)$ and $\mathrm{FC}(* *)$ are indicated at 280 and $494 \mathrm{~nm}$, respectively.

Concentrations of samples differed, resulting in different heights of absorbance peaks. 


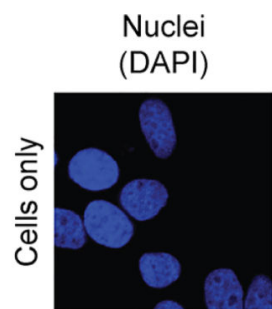

Actin filaments Conjugate (Phalloidin AF594) (AF488 or FC)

Merge
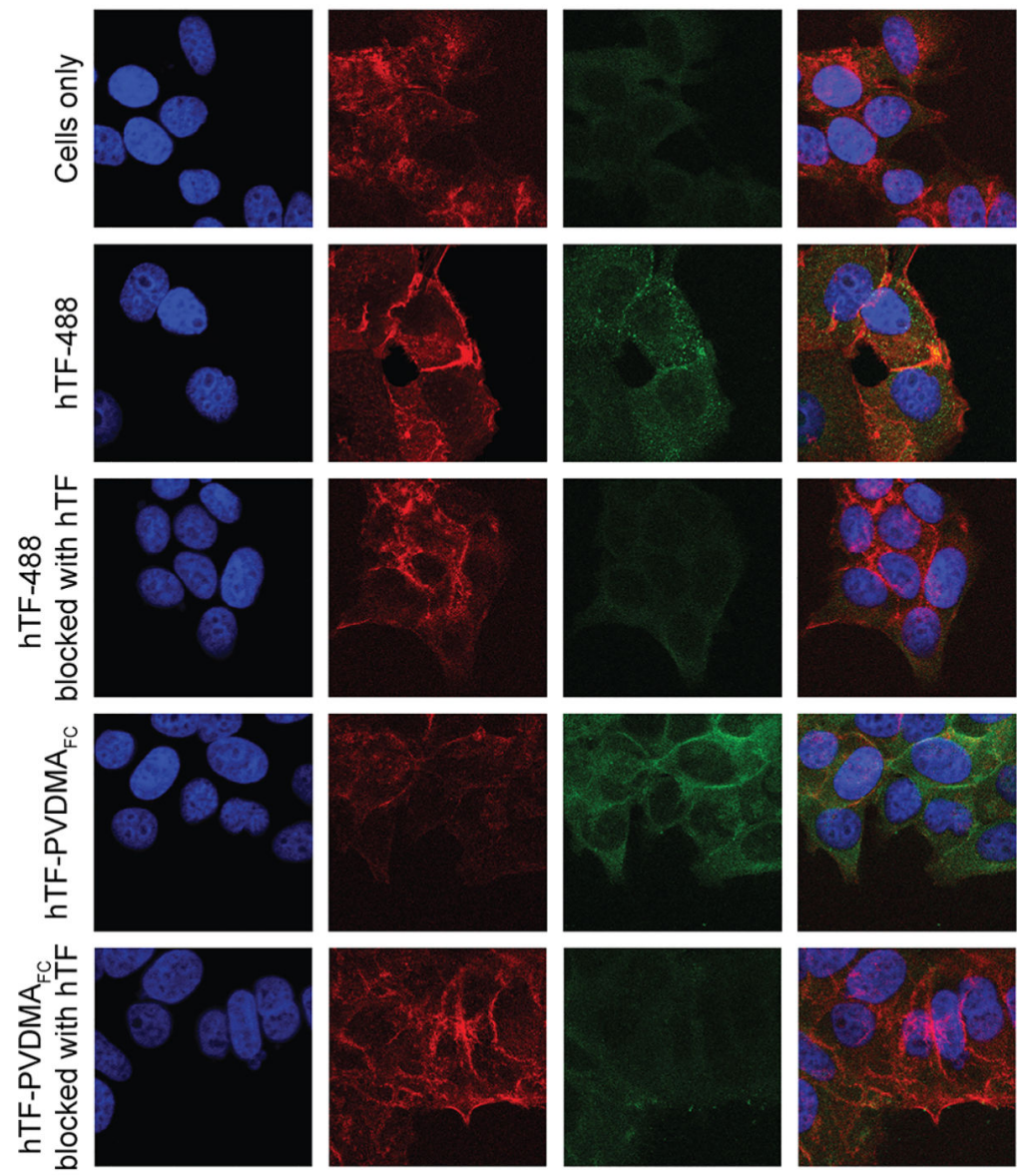

$25 \mu \mathrm{m}$

Figure 6.

hTF-PVDMA $\mathrm{FC}_{\mathrm{F}}$-mTEG targeted protein-polymer conjugates are internalized into MCF-7 cells through receptor-specific interactions. Cells not treated with protein or proteinpolymer conjugate exhibited a low background level of autofluorescence in the green channel (row 1). As a positive control, holo-transferrin protein directly labeled with fluorophore (hTF-488) was internalized into MCF-7 cells that express transferrin receptor, as seen by green punctate structures throughout the cell body (row 2). hTF-488 internalization was blocked by competition with an excess of unlabeled hTF protein (row 3). Fluorescently labeled polymer conjugated to human holo-transferrin (hTF-PVDMAFCmTEG) was similarly internalized into the cell line (row 4). Competition between hTFPVDMA $_{F C}-\mathrm{mTEG}_{\text {and }}$ excess unlabeled hTF blocked internalization and reduced signal to the level of autofluorescence (row 5), indicating that binding and internalization of the protein-polymer conjugate were mediated by specific interactions between hTF and its receptor, TFR. Cells were incubated with samples for $1 \mathrm{~h}$ at $37^{\circ} \mathrm{C}$ to allow receptormediated internalization to occur. Blue indicates DAPI stain for cell nuclei; red indicates phalloidin conjugated to Alexa Fluor 594, which stains actin filaments and helped to identify cell boundaries; and green indicates the protein or protein-polymer conjugate, with positive 
control protein labeled with Alexa Fluor 488 or polymer labeled with fluorescein cadaverine. Scale bar shown applies to all images. 


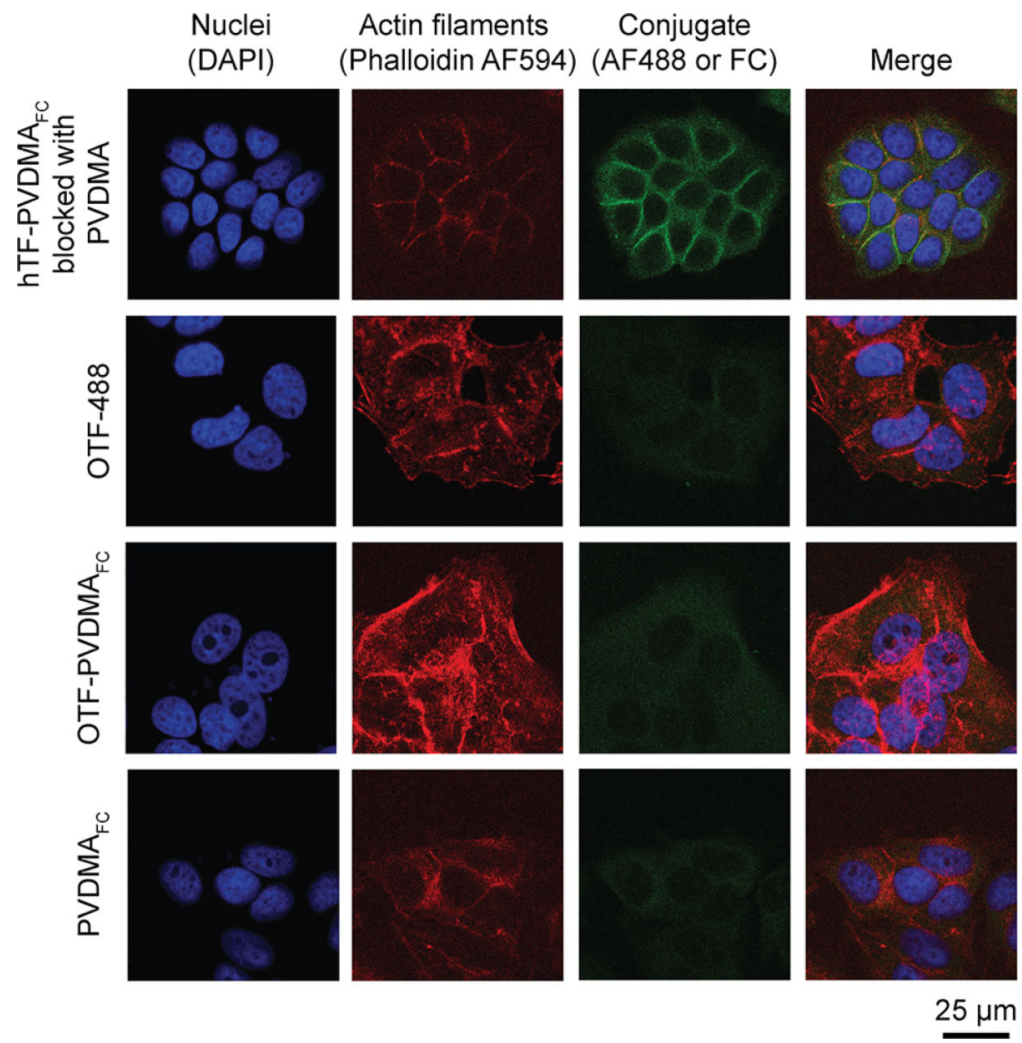

Figure 7.

Polymer does not cause nonspecific cell staining for protein-polymer conjugates. Including excess unlabeled polymer during the internalization period of hTF-PVDMA $A_{F C}-m_{T E G}$ did not block receptor-specific internalization of hTF-PVDMA ${ }_{F C}-$ mTEG (row 1). MCF-7 cells neither bound nor internalized non-targeted chicken ovotransferrin protein labeled directly with fluorophore (OTF-488) (row 2) or fluorescently labeled OTF-polymer conjugates (OTF-PVDMA ${ }_{\mathrm{FC}}-\mathrm{mTEG}$ ) (row 3). Fluorescently labeled polymer not conjugated to protein (PVDMA $_{\mathrm{FC}}-\mathrm{mTEG}$ ) similarly did not stain cells (row 4). Blue indicates DAPI stain for cell nuclei; red indicates phalloidin conjugated to Alexa Fluor 594, which stains actin filaments and helps to identify cell boundaries; and green indicates the protein or protein-polymer conjugate, with OTF control protein labeled with Alexa Fluor 488 and polymer labeled with fluorescein cadaverine. Scale bar shown applies to all images. 
Table 1.

Characterization of Polymers by ${ }^{1} \mathrm{H}$ NMR Spectroscopy and GPC

\begin{tabular}{lllcc}
\hline polymer name & mTEG eq $^{\boldsymbol{a}}$ & actual mTEG $^{\boldsymbol{b}}$ & $\boldsymbol{M}_{\mathrm{n}}(\mathrm{kg} / \mathbf{m o l})$ & $\boldsymbol{c}$ \\
PVDMA & 0 & 0 & 13.1 & 1.35 \\
PVDMA-mTEG & 0.3 & 0.28 & 20.0 & 1.25 \\
\hline
\end{tabular}

${ }^{a}$ Molar equivalents of mTEG relative to the azlactone repeat unit in the reaction.

${ }^{b}$ Molar equivalents of mTEG incorporated into the polymer, determined using ${ }^{1} \mathrm{H}$ NMR spectroscopy. 4-Iodoanisole was added as an internal standard, and mTEG functionalization was determined by comparing the integration of the ester peak at $4.22 \mathrm{ppm}$ to the integration of the peak at $6.67 \mathrm{ppm}$ arising from 4-iodoanisole.

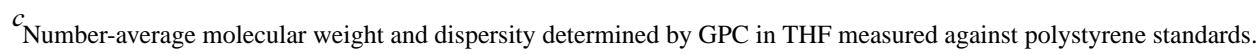

